\title{
Animal production and canopy attributes of Cynodon pasture managed under continuous stocking with wethers at three levels of forage allowance
}

\author{
Márcia Vendrúsculo dos Santos ${ }^{1}$, Gilberto Vilmar Kozloski ${ }^{1}$, Fernando Luiz Ferreira de \\ Quadros $^{1}$, Cleber Cassol Pires ${ }^{1}$, Tatiana Pfüller Wommer ${ }^{1}$, Camila Ornelas Mônego ${ }^{1}$
}

1 Universidade Federal de Santa Maria.

\begin{abstract}
The objective of the present experiment was to evaluate the effect of forage allowance $(3,6$ or $9 \mathrm{~kg}$ of green leaves dry matter (DM)/100 kg of body weight (BW)) on both animal performance and attributes of Cynodon dactylon var.dactylon canopy managed under continuous stocking by wethers. The study was carried out with 27 Polwarth wethers throughout five 28-day periods, in a completely randomized experiment, which included three paddocks per treatment and three tester animals per paddock. Forage mass varied from 2878 to $6580 \mathrm{~kg}$ of DM/ha and was directly related to forage allowance. Leaves proportion (mean of 23\%) and leaves growth rate (mean of $25 \mathrm{~kg}$ of DM/ha/day) varied between experimental periods in a similar rate for all treatments. Stocking rate varied from 652 to $2428 \mathrm{~kg}$ of LW/ha/day and was higher for the lowest forage allowance treatment. Individual BW gain (mean of $9.7 \mathrm{~g} /$ day) or gain per area (mean of $406 \mathrm{~g} / \mathrm{ha} /$ day) were only affected by experimental periods. Forage intake was neither affected by treatments nor by periods (mean of $1042 \mathrm{~g}$ of DM/day). Cynodon dactylon var. dactylon pasture may be managed under continuous stocking by grazing wethers at forage allowances varying from 3 to $9 \mathrm{~kg}$ of green leaves dry matter/100 $\mathrm{kg}$ of BW without effects on canopy attributes or animal production.
\end{abstract}

Key Words: Cynodon dactylon var. dactylon, growth rate, intake, live weight gain, sheep, tropical grass

\section{Introduction}

Pastures are the most important and least expensive forage resource for ruminant production in Brazil, and a broad variety of natural and cultivated forage species are available, including Cynodon dactylon var. dactylon. This tropical perennial grass species shows high spreading potential, high capability of adaptation to different climate and soil conditions and high persistence under grazing (Lima \& Vilela, 2005). Although this forage species has usually been considered as a recruiting invader, its traits are positive for using as pasture in continuous stocking systems. However, no technical or scientific information on the nutritional value of Cynodon dactylon var. dactylon under grazing is available, as its management is usually empirical. Additionally, scientific information could also be useful in establishing management strategies for other Cynodon species.

Adequate pasture management should consider the balance between forage yield and nutritive value, as well as the optimal productivity per animal and per area on a sustainable perspective (Coleman, 1992). Forage allowance has impacts on all of these aspects and is a recommended criterion for defining pasture management. For example, previous studies concluded that the optimal forage allowance for sheep grazing Tifton 85 (Cynodon spp.) pasture should be around 5 to $6 \mathrm{~kg}$ of dry matter (DM)/100 kg of body weight (BW) (Carnevalli et al., 2001b). However, once anatomical and physiological characteristics differ by pasture species and genus, it is unlikely that the recommended level of forage allowance is similar for all situations.

The objective of this study was to evaluate the effect of different levels of green leaves allowance of a Cynodon dactylon var. dactylon pasture managed under continuous stocking with wethers on canopy attributes and animal production.

\section{Material and Methods}

The experiment was carried out from October 2008

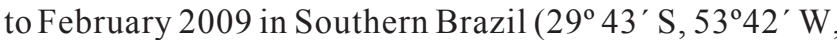
$95 \mathrm{~m}$ al). Soil is classified as Hapludalf (Argissolo Vermelho Distrófico Arenico(EMBRAPA, 1999)), which is characterized as deep, redish, sandy superficial texture and well drained. Minimum and maximum temperatures, rainfall and insolation values were observed throughout the experimental period at the Departamento de Fitotecnia weather station in 
Universidade Federal de Santa Maria, RS, which is located next to experimental area (Figure 1).

Cynodon dactylon var. dactylon pasture was previously established and was routinely used under grazing by sheep. The experimental area was similar in topography and included nine paddocks of approximately 0.18 ha each, as well as an additional 1.5-ha pasture area used under grazing by additional wethers which were eventually included in the experiment to obtain the expected forage allowance levels for each treatment. At the beginning of each experimental period, pasture was fertilized with $50 \mathrm{~kg} / \mathrm{ha}$ of $\mathrm{N}$, as urea.

Experimental treatments were three levels of green leaves dry matter (DM) allowance $(3,6$ and $9 \mathrm{~kg} / 100$ body weight) randomly distributed through the nine experimental pasture paddocks. The experiment was carried out throughout five 28 -days experimental periods. For animal performance and behavior evaluations, three one-year-old Polwarth wethers by paddock were used as tester animals. For forage intake estimates only two tester wethers per paddock were used. Additional wethers were eventually included in the trial to obtain the forage allowance levels planned for each treatment. All animals were treated with a commercial vermifuge before the evaluations and, during the experimental period, the FAMACHA method (Malan \& Van Wyk, 1992) was used for endoparasite control. Foot diseases were controlled by local treatment with $100 \mathrm{~g} /$ liter zinc sulphate solution. All procedures in the study were conducted in accordance with the guidelines of the Animal Care and Ethical Committee of the Universidade Federal de Santa Maria.

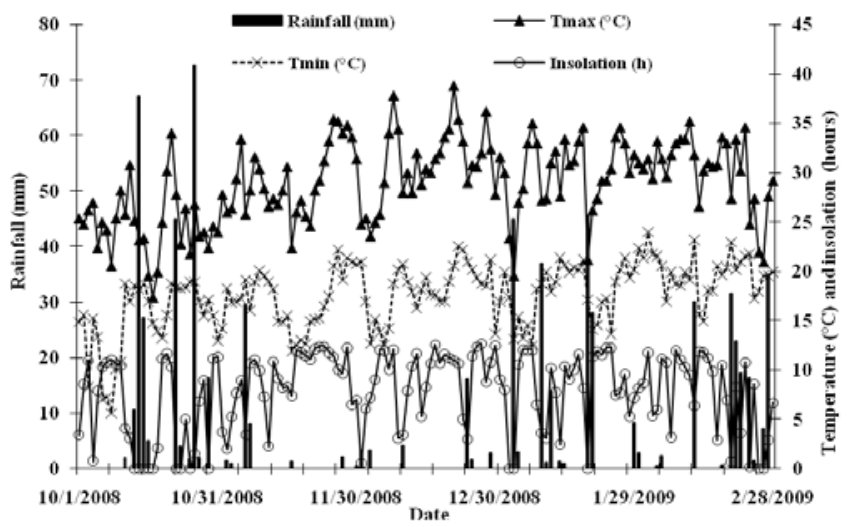

Figure 1 - Temperature $\left({ }^{\circ} \mathrm{C}\right)$, rainfall $(\mathrm{mm})$ and insolation hours observed from October 2008 to February 2009 at the Departamento de Fitotecnia weather station in Universidade Federal de Santa Maria, Santa Maria, RS, Brazil.
The put-and-take stocking method of Mott \& Lucas (1952) was used for pasture management. Animals were maintained on pasture, with free access to water and mineral salt, during a restricted time, from $9 \mathrm{~h} 00$ to $17 \mathrm{~h} 30$. During the night, they were confined in collective stalls.

Total forage mass and green leaves mass on pasture were estimated at the beginning of each experimental period through the visual double sampling method (Mannetje, 2000). Twenty $0.0625-\mathrm{m}^{2}$ quadrats were used for visual estimative of forage mass in each paddock. In five of these quadrats all above ground biomass was cut, weighed and sampled. These samples were pooled by paddock and two sub-samples were taken. One sub-sample was oven-dried $\left(55^{\circ} \mathrm{C}\right)$ and used to calculate total DM biomass and other sub-sample was separated in leaves, stems and senescent fractions, which were also oven-dried $\left(55^{\circ} \mathrm{C}\right)$.

The green leaf accumulation ( $\mathrm{kg} \mathrm{DM} / \mathrm{ha} /$ day) was estimated by using two grazing exclusion cages $\left(0.64 \mathrm{~m}^{2}\right)$ distributed in representative points of canopy in each paddock (Gardner, 1986). All above-ground biomass present in a $0.0625-\mathrm{m}^{2}$ square within the grazing exclusion apparatus was cut on the $1^{\text {st }}, 14^{\text {th }}$ and $28^{\text {th }}$ days of each experimental period, weighed and sampled. Two sub-samples were taken and processed as described above. The green leaf accumulation was calculated as the difference between the green leaves DM biomass at the beginning and at the end of each experimental period divided by the number of days of the period.

Animal stocking rate ( $\mathrm{kg}$ of body weight/ha) was adjusted at intervals of 14 days based on both initial green leaves DM biomass and green leaf accumulation as follow: $[(($ green leaf accumulation $(\mathrm{kg} / \mathrm{ha} /$ day $) \times 14)+$ green leaves DM biomass $(\mathrm{kg} / \mathrm{ha})) /(14 \times 100)] /$ intended forage allowance ( $\mathrm{kg}$ green leaves DM/100 kg body weight). Wethers were weighed at the beginning and at the end of each experimental period after 14 hours of water and feed fasting. The body weight $(\mathrm{BW})$ gain per area $(\mathrm{kg} / \mathrm{ha})$ was calculated considering the performance of tester animals.

Forage samples were taken by simulating grazing behavior of each tester animal at the end of each experimental period. These samples were oven-dried $\left(55^{\circ} \mathrm{C}\right)$, ground to pass through 1-mm screen and pooled by paddock in each period for analysis. To estimate forage intake, total feces were collected with harnesses from two tester animals in each paddock during the last four days of each experimental period. The harnesses were emptied twice daily, at $8 \mathrm{~h} 00$ and $18 \mathrm{~h} 00$, and feces were frozen $\left(-20^{\circ} \mathrm{C}\right)$. At the end of each period, all feces from each animal were weighed, homogenized and sampled. These samples were oven-dried $\left(55^{\circ} \mathrm{C}\right)$ and ground to pass through $1-\mathrm{mm}$ screen for analysis. 
Dry matter (DM) content was determined by drying at $105^{\circ} \mathrm{C}$ for at least $8 \mathrm{~h}$. Ash was determined after combustion at $600{ }^{\circ} \mathrm{C}$ for $3 \mathrm{~h}$ and organic matter (OM), by mass difference. Total $\mathrm{N}$ was assayed by a Kjeldahl method (Method 984.13; AOAC 1995). Crude protein was calculated as $\mathrm{N} \times 6.25$. The neutral (NDF) and acid (ADF) detergent fiber analysis was based on the procedures described by Mertens (2002), except that the samples were weighed into polyester filter bags (porosity of $25 \mu$ ) and treated with neutral detergent in an autoclave at $110^{\circ} \mathrm{C}$ for $40 \mathrm{~min}$ (Senger et al., 2008). The in vitro DM digestibility (IVDMD) was analyzed according to a method adapted from Goering \& Van Soest (1970), through which approximately $0.5 \mathrm{~g}$ of dried and ground forage sample is weighed in nylon bag $(4 \times 5 \mathrm{~cm}, 50 \mu$ of porosity), anaerobically incubated at $39^{\circ} \mathrm{C}$ during 48 hours in buffered rumen fluid, and residue is treated with neutral detergent solution in autoclave (Senger et al., 2008).

Forage DM intake was calculated based on fecal excretion of $\mathrm{N}$ and $\mathrm{ADF}$ through an equation originated from a controlled digestibility assay with wethers fed Cynodon dactylon var. dactylon (Oliveira, 2009), as follows: DMintake $(\mathrm{g} /$ day $)=178+(1.73 \times$ fecal $\mathrm{ADF}(\mathrm{g} /$ day $))+(64.5$ $\times$ fecal $N(\mathrm{~g} /$ day $)$ ).

Grazing behavior of tester animals was evaluated on $15^{\text {th }}$ day of each experimental period, from $9 \mathrm{~h} 00$ to $17 \mathrm{~h} 30$, through visual observation (Jamieson \& Hodgson, 1979), at intervals of ten minutes, of resting, grazing or rumination activities.

Data were analyzed using the PROC MIXED of SAS (Statistical Analysis System, version 9.1.3), whose model included the effects of treatments, the random effect of paddocks (error a), the period effect as repeated measures, the treatment $\times$ period interaction and residual error (error b). The effect of both forage allowance and period were analyzed by regression. The square sum was decomposed in linear and quadratic effects for forage allowance and in linear, quadratic and cubic effects for period. When relevant, linear regression or Pearson correlation was performed between specific quantitative variables.

\section{Results and Discussion}

The treatment $\times$ period interaction was not significant for most variables, except for the proportion of stem and senescent forage in canopy biomass. Both these variables were differently affected by forage allowance throughout the experimental periods. However, the range of treatment effects on these variables was not relevant as it did not contribute to explain animal production results. Thus, mean values of treatments and periods of all variables were shown in separated tables.

Current forage allowance means were closed to expected values (Table 1). As previously observed for other tropical grass pastures (Machado et al., 2007), forage mass increased linearly with increased levels of forage allowance (Table 1).

However, forage mass varied cubically throughout the experimental periods, showing higher values at the second and fifth periods (Table 2). On average, forage mass was higher than that previously observed in the same pasture (4573 vs $3400 \mathrm{~kg} / \mathrm{ha}$ ) under a lower rainfall condition (Soriano, 2009) compared with the rainfall values occurring in the present study.

High grazing pressure with high defoliation levels, in a continuous stocking system usually decreases canopy leaves proportion and accumulation (Parsons et al., 2000). In another way, excessive total forage biomass accumulation may decrease green leaf accumulation due both to impair by sun light penetration within the canopy and to increase in leaves senescence rate. In similar experiments carried out with sheep grazing Coastcross (Carnevalli et al., 2001a) or Tifton 85 (Carnevalli et al., 2001b) pastures, it was observed that canopy height increased from 50 to $200 \mathrm{~mm}$, and

Table 1 - Structural variables of Cynodon dactylon var. dactylon canopy managed under continuous stocking by wethers at three levels of forage allowance

\begin{tabular}{|c|c|c|c|c|c|c|}
\hline \multirow[t]{2}{*}{ Variable } & \multicolumn{3}{|c|}{ Forage allowance ${ }^{1}$} & \multirow[b]{2}{*}{$\mathrm{SE}^{2}$} & \multicolumn{2}{|c|}{$\mathrm{P}^{3}$} \\
\hline & 3 & 6 & 9 & & $\mathrm{~L}$ & Q \\
\hline Current allowance ${ }^{1}$ & 3.40 & 6.65 & 9.50 & 0.11 & $<0.001$ & 0.953 \\
\hline Forage mass (DM, kg/ha) & 3800 & 4623 & 5298 & 305 & $<0.001$ & 0.806 \\
\hline Green leaf accumulation ${ }^{4}$ (kg/ha/day) & 23.9 & 24.1 & 26.9 & 3.12 & 0.581 & 0.787 \\
\hline \multicolumn{7}{|c|}{ Structural components of the canopy ( $\%$ on total DM) } \\
\hline Leaves & 23.2 & 21.0 & 24.3 & 1.23 & 0.361 & 0.230 \\
\hline Stems & 39.1 & 37.5 & 38.7 & 2.34 & 0.929 & 0.693 \\
\hline Senescent material & 37.7 & 41.5 & 36.9 & 3.15 & 0.872 & 0.279 \\
\hline
\end{tabular}

${ }^{1} \mathrm{~kg}$ of green leaves dry matter $(\mathrm{DM}) / 100 \mathrm{~kg}$ of body weight.

2 Standard error of the mean, where $\mathrm{n}=15$ per treatment.

3 Probability of linear (L) or quadratic (Q) treatment effects by regression analysis.

${ }^{4}$ Green leaves DM accumulation. 
consequently, forage allowance, from 3 to $7 \mathrm{~kg}$ of total $\mathrm{DM} / 100 \mathrm{~kg} \mathrm{BW}$, leaves proportion reduced and senescent forage proportion increased. However,neither leaf proportion (mean of $22.8 \%$ ) nor green leaf accumulation (mean of $25 \mathrm{~kg} / \mathrm{ha} /$ day) was affected by forage allowance in the present study. Probably other factors associated with plant growth, as temperature, sun light incidence, rainfall and nutrient availability may have interacted with forage biomass on determining leaves proportion and green leaf accumulation (Gomide, 1994). In turn, both attributes were significantly affected by experimental periods. The highest green leaf accumulation mean was observed at the first period resulting in higher leaves proportion at the second period, both periods characterized by high rainfall values (Figure 1). In other way, the lowest green leaf accumulation mean was observed at the third experimental period, which was characterized by rainfall absence. Stems proportion linearly increased whereas the proportion of both leaves and senescent forage varied quadratically from the first up to the last experimental period. The lowest proportion of senescent forage was observed at the third period. The mean values of these canopy attributes were similar to those previously observed by Soriano (2009) for the same pasture. However, the green leaf accumulation was, on average, lower than values reported for other Cynodon pastures (Carnevalli et al., 2001 a and 2001b, Paciullo et al., 2005; Maixner et al, 2009).

The BW gain by grazing animals depends on the amount and on the nutritional value of ingested forage, both factors affected by forage allowance. Lower levels of forage allowance verified at increased stocking rate usually reduces the opportunity for forage selection and individual performance by grazing animals (Hodgson, 1990; Coleman, 1992). For example, BW gain by grazing wethers increased from -20 to $35 \mathrm{~g} / \mathrm{animal} /$ day when the forage allowance of a Tifton 85 pasture increased from 2.4 to $6.6 \mathrm{~kg} \mathrm{DM} / 100 \mathrm{~kg} \mathrm{BW}$ (Carnevalli et al., 2001b). However, in the present study, the initial and final $\mathrm{BW}$, as well as the individual $\mathrm{BW}$ gain or BW gain per area were not significantly affected by forage allowance (Table3). Soriano (2009) previously reported negative BW variation by wethers grazing on the same pasture (mean of $-25 \mathrm{~g} / \mathrm{animal} /$ day) regardless of the level of forage allowance. In turn, BW gain per area by wethers grazing a Coastcross pasture linearly increased from

Table 2 - Structural variables of the Cynodon dactylon var. dactylon canopy managed under continuous stocking by wethers throughout five 28-day experimental periods

\begin{tabular}{|c|c|c|c|c|c|c|c|c|c|}
\hline \multirow[t]{2}{*}{ Variable } & \multicolumn{5}{|c|}{ Period $^{1}$} & \multirow[b]{2}{*}{$\mathrm{R}^{2}$} & \multicolumn{3}{|c|}{$\mathrm{P}^{2}$} \\
\hline & 1 & 2 & 3 & 4 & 5 & & $\mathrm{~L}$ & Q & $\mathrm{C}$ \\
\hline Forage mass (DM, kg/ha) & 3560 & 4651 & 4520 & 4427 & 5708 & 0.39 & $<0.001$ & 0.713 & 0.009 \\
\hline Green leaf accumulation ( $\mathrm{kg} / \mathrm{ha} /$ day) & 39.0 & 29.4 & 12.3 & 25.6 & 18.5 & 0.31 & 0.001 & 0.026 & 0.327 \\
\hline \multicolumn{10}{|c|}{ Structural components of the canopy ( $\%$ on total DM) } \\
\hline Leaves & 20.3 & 28.2 & 26.5 & 20.6 & 18.5 & 0.49 & 0.013 & $<0.001$ & 0.003 \\
\hline Stem & 24.6 & 33.2 & 42.9 & 43.9 & 47.5 & 0.62 & $<0.001$ & 0.034 & 0.822 \\
\hline Senescent & 55.1 & 38.6 & 30.6 & 35.5 & 34.0 & 0.52 & $<0.001$ & $<0.001$ & 0.102 \\
\hline
\end{tabular}

$\mathrm{DM}=$ dry matter.

${ }^{1}$ From October 2008 to February 2009

2 Probability of linear (L), quadratic (Q) or cubic (C) effects of experimental periods by regression analysis.

${ }^{3}$ Green leaves DM accumulation.

Table 3 - Animal production, forage intake and grazing time by wethers on a Cynodon dactylon var. dactylon pasture managed under continuous stocking at three levels of forage allowance

\begin{tabular}{|c|c|c|c|c|c|c|}
\hline \multirow[t]{2}{*}{ Variable } & \multicolumn{3}{|c|}{ Forage allowance ${ }^{1}$} & \multirow[b]{2}{*}{$\mathrm{SE}^{2}$} & \multicolumn{2}{|c|}{$\mathrm{P}^{3}$} \\
\hline & 3 & 6 & 9 & & $\mathrm{~L}$ & Q \\
\hline Initial BW (kg) & 35.0 & 34.1 & 34.3 & 0.67 & 0.956 & 0.844 \\
\hline Final BW (kg) & 34.0 & 36.0 & 36.5 & 0.72 & 0.101 & 0.173 \\
\hline Individual BW gain (g/day) & -1.50 & 14.3 & 16.4 & 5.33 & 0.086 & 0.422 \\
\hline Stocking rate $(\mathrm{kg} \mathrm{BW/ha)}$ & 1858 & 979 & 862 & 84.7 & $<0.001$ & $<0.001$ \\
\hline Gain per area (g BW/ha/day) & 151 & 496 & 572 & 332 & 0.521 & 0.812 \\
\hline Forage intake (g DM/day) & 977 & 1103 & 1047 & 75.5 & 0.179 & 0.045 \\
\hline Grazing time (minutes/day) ${ }^{4}$ & 457 & 476 & 440 & 8,80 & 0.120 & 0.001 \\
\hline
\end{tabular}

$\mathrm{BW}=$ body weight; $\mathrm{DM}=$ dry matter.

${ }^{1} \mathrm{~kg}$ of green leaves DM/100 kg of body weight.

${ }^{2}$ Standard error of the mean, where $\mathrm{n}=15$ per treatment, except for initial and final body weight, which were measured at the beginning and at the end of experiment, respectively, where $\mathrm{n}=9$ per treatment.

${ }^{3}$ Probability of linear (L) or quadratic (Q) treatment effects by regression analysis.

${ }^{4}$ Observed from 9 h00 to $17 \mathrm{~h} 30 \mathrm{~min}$. During the night, animals were confined in collective stalls. 
$600 \mathrm{~g} / \mathrm{ha} /$ day at a forage allowance of $5.2 \mathrm{~kg} \mathrm{DM} / 100 \mathrm{~kg} \mathrm{BW}$ to $1600 \mathrm{~g} / \mathrm{ha} /$ day at a forage allowance of $7 \mathrm{~kg} \mathrm{DM} / 100 \mathrm{~kg}$ BW (Carnevalli et al., 2001a).

Although it was not affected by treatments, individual BW gain varied throughout the experimental periods (Table 4). The highest BW gain means, both per animal and per area, were observed at the second experimental period, which was coincident with higher rainfall and higher leaves proportion in pasture canopy. During the following experimental periods, animal BW gain was negative or near zero. Stocking rate significantly decreased at the third experimental period, when no rainfall occurred and the lowest forage accumulation rate was observed. Forage intake, in turn, was neither affected by forage allowance (Table 3) nor by periods (Table 4). On average, forage intake was $1042 \mathrm{~g} \mathrm{DM} /$ day, whose value is slightly lower than that estimated by the NRC (2007) for wethers (i.e., approximatelly $1200 \mathrm{~g} \mathrm{DM}$ /day) whereas it is higher than those reported in other studies with wethers grazing on Cynodon pastures (Moreira et al., 2001; Carnevalli et al., $2001 \mathrm{~b}$; Soriano, 2009). Results of animal BW gain in the present study showed high variability (i.e., coefficient of variation above $300 \%$ ), indicating that several different canopy structures were available to animals during grazing activity. At any time, equal forage mass or allowance may be spatially arranged under infinite combinations of high, density and anatomical distribution, all affecting the selectivity and the amount of ingested forage (Heringer \& Carvalho, 2002; Carvalho \& Moraes, 2005). Moreover, results also indicate that sheep potential for searching, selecting and consuming high nutritive forage from a heterogeneous pasture canopy as Cynodon is variable and so this potential should be included as a selection criteira in animal breeding programs.

The content of OM, crude protein (CP) and NDF, as well as the in vitro dry matter digestibity (IVDMD) of pasture samples collected through grazing simulation were not affected by forage allowance (Table 5). However, OM content decreased whereas the CP and NDF contents, as well as the IVDMD, varied quadratically throughouth the experimental periods (Table 6). The highest NDF values and the lowest $C P$ and IVDMD values were observed at the third period.

Results of animal production throughout the experimental periods was neither coherent with the forage intake nor with the chemical composition or digestibility mean values of forage samples collected through grazing simulation. Although the explanation is not apparent, it is

Table 4 - Animal production, forage intake and grazing time by wethers on a Cynodon dactylon var. dactylon pasture managed under continuous stocking throughout five 28 days experimental periods

\begin{tabular}{|c|c|c|c|c|c|c|c|c|c|}
\hline \multirow[t]{2}{*}{ Variable } & \multicolumn{5}{|c|}{ Period $^{1}$} & \multirow[b]{2}{*}{$\mathrm{R}^{2}$} & \multicolumn{3}{|c|}{$\mathrm{P}^{2}$} \\
\hline & 1 & 2 & 3 & 4 & 5 & & $\mathrm{~L}$ & Q & $\mathrm{C}$ \\
\hline Mean BW (kg) & 34.5 & 35.7 & 36.5 & 36.4 & 35.8 & 0.08 & 0.027 & 0.011 & 0.998 \\
\hline Individual BW gain (g/day) & 8.3 & 71.1 & 1.8 & -13.1 & -19.4 & 0.49 & $<0.001$ & 0.040 & $<0.001$ \\
\hline Stocking rate $(\mathrm{kg} \mathrm{BW} / \mathrm{ha})$ & 1335 & 1574 & 992 & 1103 & 1163 & 0.09 & 0.152 & 0.615 & 0.176 \\
\hline Gain per area (g BW/ha/day) & -31 & 2987 & -55 & -191 & -677 & 0.43 & 0.003 & 0.020 & $<0.001$ \\
\hline Forage intake (g DM/day) & 1014 & 1038 & 1013 & 1080 & 1054 & 0.01 & 0.411 & 0.967 & 0.759 \\
\hline Grazing time $(\mathrm{min} / \text { day })^{3}$ & 427 & 435 & 470 & 483 & 475 & 0.29 & $<0.001$ & 0.026 & 0.031 \\
\hline
\end{tabular}

$\mathrm{BW}=$ body weight; $\mathrm{DM}=$ dry matter.

${ }^{1}$ From October 2008 to February 2009

2 Probability of linear (L), quadratic (Q) or cubic (C) effect of experimental periods by regression analysis.

3 Observed from 9 h00 to $17 \mathrm{~h} 30 \mathrm{~min}$. During the night, animals were confined in collective stalls.

Table 5 - Chemical composition and in vitro dry matter digestibility (IVDMD) of forage samples collected through grazing simulation from a Cynodon dactylon var. dactylon pasture managed under continous stocking by wethers at three levels of forage allowance

\begin{tabular}{|c|c|c|c|c|c|c|}
\hline \multirow[t]{2}{*}{ Variable } & \multicolumn{3}{|c|}{ Forage allowance ${ }^{1}$} & \multirow[b]{2}{*}{$\mathrm{SE}^{2}$} & \multicolumn{2}{|c|}{$\mathrm{P}^{3}$} \\
\hline & 3 & 6 & 9 & & $\mathrm{~L}$ & Q \\
\hline Dry matter $(\mathrm{g} / \mathrm{kg})$ & 377 & 383 & 414 & 7.8 & 0.086 & 0.508 \\
\hline \multicolumn{7}{|c|}{ Composition (g/kg dry matter) } \\
\hline Organic matter & 929 & 931 & 932 & 5.3 & 0.494 & 0.905 \\
\hline Crude protein & 149 & 157 & 131 & 7.6 & 0.167 & 0.120 \\
\hline Neutral detergent fiber & 752 & 744 & 747 & 3.2 & 0.096 & 0.167 \\
\hline IVDMD & 0.54 & 0.57 & 0.55 & 0.006 & 0.577 & 0.100 \\
\hline
\end{tabular}

${ }_{1}^{1} \mathrm{~kg}$ of green leaves dry matter/100 kg of body weight.

2 Standard error of the mean, where $\mathrm{n}=15$ per treatment.

${ }^{3}$ Probability of linear (L) and quadratic (Q) effect of treatments by regression analysis. 
Table 6 - Chemical composition and in vitro dry matter digestibility (IVDMD) of forage samples collected through grazing simulation from a Cynodon dactylon var. dactylon pasture managed under continous stocking by wethers through five 28-day experimental periods

\begin{tabular}{|c|c|c|c|c|c|c|c|c|c|}
\hline \multirow[t]{2}{*}{ Variable } & \multicolumn{5}{|c|}{ Period $^{1}$} & \multirow[b]{2}{*}{$\mathrm{R}^{2}$} & \multicolumn{3}{|c|}{$\mathrm{P}^{2}$} \\
\hline & 1 & 2 & 3 & 4 & 5 & & $\mathrm{~L}$ & Q & $\mathrm{C}$ \\
\hline Dry matter (g/kg) & 440 & 380 & 450 & 318 & 368 & 0.26 & $<0.001$ & 0.774 & 0.357 \\
\hline \multicolumn{10}{|c|}{ Composition (g/kg dry matter) } \\
\hline Organic matter & 936 & 934 & 938 & 925 & 922 & 0.29 & $<0.001$ & 0.095 & 0.594 \\
\hline Crude protein & 192 & 127 & 107 & 163 & 140 & 0.58 & 0.013 & $<0.001$ & $<0.001$ \\
\hline Neutral detergent fiber & 739 & 742 & 770 & 747 & 751 & 0.15 & 0.117 & 0.027 & 0.933 \\
\hline IVDMD & 0.59 & 0.59 & 0.46 & 0.58 & 0.55 & 0.24 & 0.058 & 0.004 & 0.799 \\
\hline
\end{tabular}

${ }^{1}$ From October 2008 to February 2009

2 Probability of linear (L), quadratic (Q) or cubic (C) effect of experimental periods by regression analysis.

likely that these forage samples were not representative of forage ingested by animals, especially at the last two experimental periods. In these periods, it is likely that wethers ingested forage containing high proportion of stems and senescent plant components, which is expected to have IVDMD lower than those observed for the samples collected through grazing simulation. In this situation, because lignified stems usually have high resistence to being grazed, the forage mass ingested at each bite is reduced and, as a compensatory mechanism, grazing time by wethers is increased (Carvalho \& Moraes, 2005). Grazing time showed a quadratic response to forage allowance (Table 3), whereas it linearly increased from the first to the fifth experimental period (Table 4) in the present study. Maintenance energy requirement by animals is increased as consequence of increased grazing time, which may also have accounted for the BW gain reduction in the last experimental periods.

Forage mass and proportion of leaves are attributes which affect forage accumulation, grazing selection and performance of grazing animals (Santos et al., 2006). There was no significant correlation between forage mass and animal production in the present study. However, BW gain by wethers was directly related to proportion of leaves in the canopy (Figure 2). Although the linear regression between both variables showed a relatively low $\mathrm{R}^{2}$ due to the high variability of $\mathrm{BW}$ gain data, it indicates that positive BW gains would be expected only when the DM of green leaves represents more than $25 \%$ of total forage DM mass. As previously reported in other studies (Carvalho et al., 2001, Boval et al., 2007), results of the present study indicate that not only the forage allowance, but also leaves distribution in canopy strucuture and individual animal potential for accessing and ingesting high quality forage affects the nutrients supply and performance of grazing sheep.

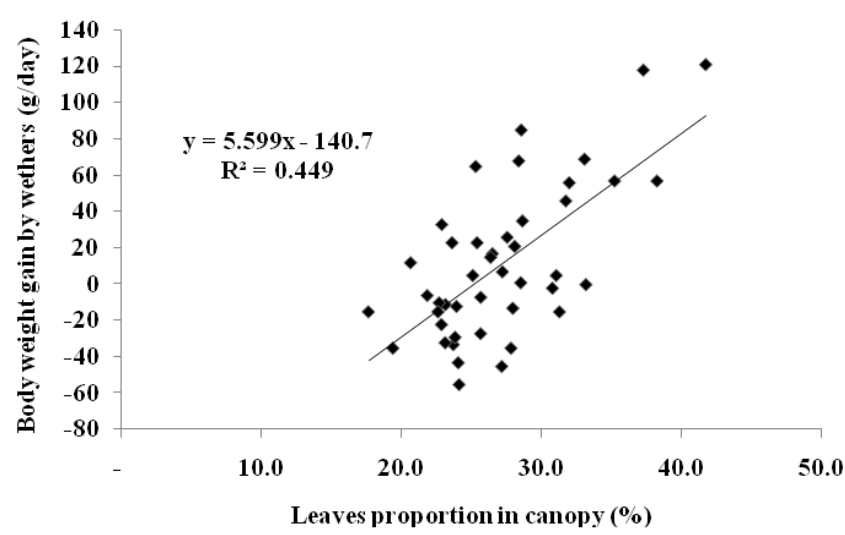

Figure 2 - Relation between leaves proportion in canopy (dry matter basis) and individual body weight gain by wethers grazing on Cynodon dactylon var. dactylon pasture $(\mathrm{n}=44 ; \mathrm{P}<0.05)$.

\section{Conclusions}

Cynodon dactylon var. dactylon pasture can be managed under continuous stocking by grazing wethers at forage allowances varying from 3 to $9 \mathrm{~kg}$ green leaves dry matter $/ 100 \mathrm{~kg}$ live weight without affecting canopy attributes or animal production.

\section{References}

ASSOCIATION OF OFFICIAL ANALYTICAL CHEMISTS - AOAC Official methods of analysis. 16.ed. Washington: AOAC International, 1995. 1094p.

BOVAL, M.; FANCHONE, A.; ARCHIMÈDE, H. et al. Effect of structure of a tropical pasture on ingestive behaviour, digestibility of diet and daily intake by grazing cattle. Grass and Forage Science, v.62, p.44-54, 2007.

CARNEVALLI, R.A.; SILVA, S.C.; CARVALHO, C.A.B. et al Desempenho de ovinos e respostas de pastagens de Coastcross submetidas a regimes de desfolha sob lotação contínua. Pesquisa Agropecuária Brasileira, v.36, p.919-927, 2001 a.

CARNEVALLI, R.A.; SILVA, S.C.; FAGUNDES, J.L. et al. Desempenho de ovinos e respostas de pastagens de tifton 85 (Cynodon spp.) sob lotação contínua. Scientia Agricola, v.58, p.7-15, $2001 \mathrm{~b}$. 
CARVALHO, P.C.F.; RIBEIRO FILHO, H.M.N.; POLI, C.H.C. et al. Importância da estrutura da pastagem na ingestão e seleção de dietas pelo animal em pastejo. In: REUNIÃO ANUAL DA SOCIEDADE BRASILEIRA DE ZOOTECNIA, 2001, Piracicaba. Anais... Piracicaba: SBZ, 2001. p.853-871.

CARVALHO, P.C.F.; MORAES, A. Comportamento ingestivo de ruminantes: bases para o manejo sustentável do pasto. In: MANEJO SUSTENTÁVEL EM PASTAGEM, 2005, Maringá. Anais... Maringá: UFPR, 2005. p.1-20.

COLEMAN, S.W. Plant-animal interface. Journal of Production Agriculture, v.5, p.7-13, 1992.

EMPRESA BRASILEIRA DE PESQUISA AGROPECUÁRIA EMBRAPA. Centro Nacional de Pesquisa de Solos. Sistema Brasileiro de classificação de solos. Brasília: EMBRAPA, 1999. 412 p.

GARDNER, A.L. Técnicas de pesquisa em pastagens e aplicabilidade de resultados em sistemas de produção. Brasília: IICA/EMBRAPA-CNPGL, 1986. 197p.

GOERING, H.K.; VAN SOEST, P.J. Forage fiber analysis: apparatus reagents, procedures and some applications. Washington, D.C.: USDA, 1970. 20p. (Agricultural Handbook, 379).

GOMIDE, J.A. Fisiologia do crescimento livre de plantas forrageiras. In: PEIXOTO, A.M.; MOURA, J.C.; FARIA, V.P. (Eds.) Pastagens: fundamentos da exploração racional. Piracicaba: FEALQ, 1994. p.1-14.

HERINGER, I.; CARVALHO, P.C.F. Ajuste da carga animal em experimentos de pastejo: uma nova proposta. Ciência Rural, v.32, p.675-679, 2002.

HODGSON, J. Grazing management: science into practice. New York: John Wiley \& Sons, 1990. 203p.

JAMIESON, W.S.; HODGSON, J. The effect of daily herbage allowance and sward characteristics upon the ingestive behavior of calves under strip-grazing management. Grass and Forage Science, v.34, p.261-271, 1979.

LIMA, J.A.; VILELA, D. Formação e manejo de pastagens de Cynodon. In: VILELA, D.; RESENDE, J.C.; LIMA, J. (Eds.) Cynodon: Forrageiras que estão revolucionando a pecuária brasileira. Juiz de Fora: EMBRAPA, 2005. p.11-32.

MACHADO, L.A.M.; FABRICIO, A.C.; ASSIS, P.G.G. et al. Estrutura do dossel em pastagens de capim-marandu submetidas a quatro ofertas de lâminas foliares. Pesquisa Agropecuária Brasileira, v.42, p.1495-1501, 2007.

MAIXNER, A.R.; MONTARDO, D.P.; KOZLOSKI, G.V. et al. Desempenho animal e produtividade de pastagens tropicais no noroeste do Rio Grande do Sul. Arquivo Brasileiro de Medicina Veterinária e Zootecnia, v.61, p.927-934, 2009.

MALAN, F.S.; VAN WYK, J.A. The packed cell volum and color of the conjunctivae as aids for monitoring Haemonchus contortus infestations in sheep. In: BIENNIAL NATIONAL VETERINARY CONGRESS, 1., 1992, Grahamstown, South African. Proceedings... Grahamstown: South African Veterinary Association, 1992. v.1, p.139.

MANNETJE, L.T. Measuring biomass of grassland vegetation In: MANNETJE, L.T.; JONES, R.M. (Eds.) Field and laboratory methods for grassland and animal production research. Cambridge: CABI, 2000. p.151-178.

MERTENS, D.R. Gravimetric determination of amylase-treated neutral detergent fibre in feeds with refluxing beakers or crucibles: A collaborative study. Journal of the Association of Official Analytical Chemists, v.85, p.1217-1240, 2002.

MOREIRA, A.L.; PEREIRA, O.G.; GARCIA, R. et al. Consumo e digestibilidade aparente dos nutrientes da silagem de milho e dos fenos de alfafa e de capim-Coastcross em ovinos. Revista Brasileira de Zootecnia, v.30, p.1099-1105, 2001.

MOTT, G.O.; LUCAS, H.L. The design, conduct and interpretation of grazing trials in cultivated and improved pastures. In: INTERNATIONAL GRASSLANDS CONGRESS, 6., 1952, State College. Proceedings... State College: Pennsylvania, State College Press, 1952. p.1380-1385.

NATIONAL RESEARCH COUNCIL - NRC. Nutrient requirements of small ruminants. Washington, D.C.: National Academy Press, 2007. 362p.

OLIVEIRA, L. Métodos em nutrição de ruminantes: estimativa do consumo através de índices fecais e estimativa de síntese microbiana ruminal. 2009. 78f. Dissertação (Mestrado em Zootecnia) - Universidade Federal de Santa Maria, Santa Maria.

PACIULLO, D.S.C.; AROEIRA, L.J.M.; MORENZ, M.J.F. et al Morfogênese, características estruturais e acúmulo de forragem em pastagem de Cynodon dactylon, em diferentes estações do ano. Ciência Animal Brasileira, v.6, p.233-241, 2005.

PARSONS, A.J.; CARRÈRE P.; SCHWINNING, S. Dynamics of heterogeneity in a grazed sward. In: LEMAIRE, G.; HODGSON, J.; MORAES, A. et al. (Eds.) Grassland ecophysiology and grazing ecology. Wallingford: CABI Publishing, 2000. p.289-315.

SANTOS, P.M.; CORSI, M.; PEDREIRA, C.G.S. et al. Tiller cohor development and digestibility in Tanzania guinea grass (Panicum maximum cv. Tanzania) under three levels of grazing intensity. Tropical Grasslands, v.40, p.84-93, 2006.

SENGER, C.C.D.; KOZLOSKI, G.V.; BONNECARRÈRE SANCHEZ, L.M. et al. Evaluation of autoclave procedures for fiber analysis in forage and concentrate feedstuffs. Animal Feed Science and Technology, v.146, p.169-174, 2008.

SORIANO, V.S. Utilização da pastagem de cynodon dactylon var.dactylon com diferentes níveis de oferta de lâminas foliares verdes para ovinos. 2009. 42f. Dissertação (Mestrado em Zootecnia) - Universidade Federal de Santa Maria, Santa Maria. 